\title{
REPRODUCTIVE PERFORMANCE AND GONADAL HISTOLOGICAL INVESTIGATION OF FLORIDA RED TILAPIA HYBRID BROODSTOCK REARED AT DIFFERENT LEVELS OF WATER SALINITY
}

\author{
G.D.I. Hassanen ${ }^{1}$, M. A. Amer ${ }^{2}$, M. Salem ${ }^{1}$ and H. E. Abd Elnabi ${ }^{1 *}$ \\ 1. Fish Resources and Aquaculture Department, Faculty of Environmental Agricultural Sciences, Arish \\ University, 2. Animal Production Department, Faculty of Agriculture, Ain Shams University \\ *Corresponding author: hebaabdelnabi87@yahoo.com
}

\section{SUMMARY}

The suitability of red hybrid tilapias for brackish and seawater culture is suggested by the salinity tolerance exhibited by these parental species, which are known to be moderately (O. niloticus and O. aureus) to highly (O. mossambicus and $O$. hornorum) euryhaline. The reproductive performance of Florida red tilapia broodstock at salinities of 2, 8, 14, 20 and 26 ppt was studied. Spawning was observed at all salinities. Four spawnings were obtained during the experimental period, and it was noted that there are significant differences between the treatments $(P<0.05)$. The treatment of 2ppt recorded the best and the treatment of 26ppt the lowest results in most reproductive performance parameters. At the end of the experiment, the treatment of 20 ppt was recorded the smallest diameter measurements of eggs $(22.15 \pm 1.41 \mu \mathrm{m})$ and the treatment of 8 ppt recorded the largest one $(25.50 \pm 0.76 \mu \mathrm{m})$. The histological changes that appeared in the ovaries and testes of these fish after the end of the experiment, was recorded.

\section{Keywords: Red tilapia, broodstock, salinity, seed production, histology}

\section{INTRODUCTION}

A red tilapia strain originating in Florida, USA was selected by Caribbean Marine Research Centre (CMRC) for seawater culture trials in the Bahamas due to the high salinity tolerance of both its parental species ( $O$. hornorum and $O$. mossambicus). A preliminary study showed higher growth and food conversion of juvenile and monosex males Florida red tilapia in brackish and seawater than in freshwater (Watanabe et al., 1988). Female tilapia have individual patterns of ovarian development so that in breeding populations they tend to spawn asynchronously every 3 to 4 weeks, depending upon environmental conditions (Coward and Bromage, 2000). Low fecundity and asynchronous spawning behavior are major constraints on mass tilapia seed production (Little and Hulata, 2000). Salinity is one of the important abiotic environmental factors that direct fish growth (Mommsen, 1998). When fish are forced to deal with different salinities, depending on marine or freshwater fish, they spend more energy to hold their homeostasis and grow less. Because osmoregulations break down, fish spends more energy to hold sodium and chloride ions in their bodies or take them off.

The euryhaline tilapias are known to reproduce under saline conditions (Wohlfarth and Hulata, 1983), however, there is a lack of information on reproductive performance at various salinities. For the saltwater tilapia culturist, spawning under elevated salinities provides the important advantages of minimizing freshwater requirements for maintaining broodstock and early rearing of fry (Watanabe and Kuo, 1985) and improving growth and survival of fry in brackishwater or full-strength seawater (Watanabe et al., 1989a).Water salinity has been also reported to affect the reproduction of tilapia. Gonadal development and spawning of Nile tilapia occurred at salinities of 17-29\%, while the onset of reproduction was delayed with increasing water salinity from 25 to $50 \%$ and reproduction stopped completely at salinity above 30\%o (FinemanKalio, 1988). On the other hand, Watanabe and Kuo (1985) found that the total number of spawnings of Nile tilapia females was greater in brackish water (5$15 \%$ ) than in either full strength seawater $(32 \%)$ or freshwater.

The feasibility of rearing red tilapia hybrid in brackish and seawater was first studied by Liao and Chang (1983) who reported good growth of Taiwanese red tilapia (O. mossambicus and $O$. niloticus) at salinities of $17 \mathrm{ppt}$ and $37 \mathrm{ppt}$. Although, fish appeared susceptible to handling stress. Seawater-rearing studies of Taiwanese red tilapia in Kuwait (Hopkins et al., 1985) showed that survival at $38-41$ ppt was impaired at water temperatures below $24^{\circ} \mathrm{C}$.One of the constraints in the culture of tilapias in high saline environments is sensitivity to handling and secondary infections (Chang and Plumb, 1996). Hence, tilapias reared in high salinities experience higher disease outbreaks and mortalities than those that are reared in freshwater environment. Because of these problems, there have been intensive research efforts on improving the salinity tolerance of tilapias either through modifications in the culture techniques or stock improvement.

The current study aimed to evaluate the influencing of different levels of water salinity 2,8 , 14,20 and $26 \mathrm{ppt}$ on reproductive performance and gonadal histological structure of red tilapia hybrid (Oreochromis sp.). 


\section{MATERIALS AND METHODS}

The current study was conducted at Mariculture Research Center (MRC), Faculty of Environmental Agricultural Sciences, Arish University, North Sinai, Egypt. The study was carried out from 20 July to 7 November, 2014 for a period of 110 days to evaluate the reproductive performance under salinities of 2,8 , 14,20 and 26 ppt. In five u-shaped fiberglass tanks $(320 \mathrm{~L} \times 150 \mathrm{~W} \times 100 \mathrm{H} \mathrm{cm})$, each tank was filled with $2.88 \mathrm{~m}^{3}$ of water $(60 \mathrm{~cm}$ of water depth) and supplied with compressed air. Each tank was equally separated by fine mesh as a replicate and each part stocked with 4 fishes ( 3 females and 1 male). In total, thirty females of red tilapia with an average total length $17.2 \pm 2.5 \mathrm{~cm}$ and with an average total body weight $119.1 \pm 5.8 \mathrm{~g}$, and ten males with an average total length $20.8 \pm 1.5 \mathrm{~cm}$ and with an average body weight $184.4 \pm 7.1 \mathrm{~g}$ were obtained from experimental broodstock at the MRC. Water of different salinities was prepared by diluting artesian well water (20.5 ppt) with fresh water for tanks of 2, 8, 14 and 20 ppt. Salinity was decreased by $2 \mathrm{~g} \mathrm{l}^{-1}$ day $^{-1}$ for fish acclimatization according to de Azevedo et al. (2015). Salinity was increased by $2 \mathrm{~g} \mathrm{l}^{-1}$ day $^{-1}$ using instant sea salts for tank of 26 ppt only. Sediments and wastes were removed by siphon and one- fourth of the water was changing every day. A thirty $\mathrm{cm}$ in length of PVC (polyvinyl chloride) pipe section (10 $\mathrm{cm}$ diameter) was chopped longitudinally and placed in each part of tank served as a refuge for subordinate individuals.

Broodstock were fed a rate of $2 \%$ of total biomass ad libitum diet containing $29.85 \%$ protein as shown in Table 1.

Table 1. Ingredients composition and chemical analysis of fish diet (\% on dry matter basis)

\begin{tabular}{|c|c|}
\hline Ingredients Composition & $(\%)$ \\
\hline Fish meal $(70 \% \mathrm{CP})$ & 20 \\
\hline Soybean meal $(44 \% \mathrm{CP})$ & 20 \\
\hline Yellow corn & 22 \\
\hline Wheat bran & 10 \\
\hline Rice bran & 20 \\
\hline Linseed oil & 2 \\
\hline Palm pollen & 2 \\
\hline Vitamins premix $^{(1)}$ & 2 \\
\hline Minerals premix ${ }^{(2)}$ & 2 \\
\hline \multicolumn{2}{|l|}{ Chemical Analysis (\%) } \\
\hline Crude protein $(\mathrm{CP})$ & 29.85 \\
\hline Ether extract (EE) & 5.53 \\
\hline Ash & 5.44 \\
\hline Crude fiber (CF) & 5.24 \\
\hline Nitrogen free extract (NFE) & 53.94 \\
\hline \multicolumn{2}{|c|}{$\begin{array}{l}\text { (1): One kilogram from vitamin premix contained } 10.000 .000 / \mathrm{Iu} \text {, } \\
2.000 .000 / \mathrm{Iu}, 10.000 \mathrm{~g}, 1000 \mathrm{mg}, 1000 \mathrm{mg}, 5000 \mathrm{mg}, 2000 \mathrm{mg}, 10 \\
\mathrm{mg}, 50 \mathrm{mg}, 10.000 \mathrm{mg}, 30.000 \mathrm{mg}, 1000 \mathrm{mg}, 500 \mathrm{mg}, 20.000 \mathrm{mg} \text {, } \\
10.000 \mathrm{mg}, 1000 \mathrm{mg}, 1000 \mathrm{mg} \text { and } 50 \mathrm{mg} \text { of Vitamin A, D3, E, K3, } \\
\mathrm{B} 1, \mathrm{~B} 2, \mathrm{~B} 6, \mathrm{~B} 12 \text {, Biotin, C, Nicotinic acid, Pantothenic acid, Folic } \\
\text { acid, D. L. methionine, L. lysine, L. threonine, L. tryptophan and } \\
\text { propylene glycol respectively. } \\
\text { (2): One kilogram from minerals premix contained } 3000 \mathrm{mg}, 100 \\
\mathrm{mg}, 5000 \mathrm{mg}, 4000 \mathrm{mg}, 100 \mathrm{mg}, 1000 \mathrm{mg}, 1000 \mathrm{mg}, 76500 \mathrm{mg} \text { and } \\
36000 \mathrm{mg} \text { of minerals Fe, Co, Mg, Zn, Se, Cu, I, P and Ca } \\
\text { respectively. }\end{array}$} \\
\hline
\end{tabular}

At each feeding, females were observed for mouth brooding activity and spawn date recorded. The eggs in the mouth of females are easily observed by visual inspection from outside the tank and are clear indicators of reproduction. Thirty eggs per female were taken from fishes of each tank to compare the egg diameter. Fry harvesting were carried out every 7-10 days, fry yield were collected by fine nets then counted and weighted from each female to calculate the productivity of fry.

The parameters used to determine the reproductive performance were total number of fry/treatment, mean number of fry/spawning, total fry weight $(\mathrm{g})$, mean fry weight $(\mathrm{g})$ /spawning, number of fry/female, number of fry/female/ day, number of fry $/ \mathrm{Kg}$ female, number of fry $/ \mathrm{m}^{3} /$ day, rest period (days), number of spawnings (spawning frequency), spawned females \% and average egg diameter ( $\mathrm{mm}$ ) was determined by the geometric mean of the larger and smaller diameters of each egg on a sample of 30 eggs per female according to Siraj et al. (1983). At the end of study, the testes and ovaries of all fish individuals were removed carefully from the fish in isotonic saline solution, after which, they were fixed in Bouin's solution for 24 hours. The material were then preserved in $70 \%$ ethyl alcohol, dehydrated in graded series of alcohol, cleared in xylene and embedded in paraffin wax as usual. Sometimes, tyrpinol was used for clearing and showed best results. Sections of 4-6 $\mu$ thickness were mounted on chemically clean glass slides. The sections were prepared then stained with Harri's Haematoxylin and Eosin (Hx and E) according to Pearse (1972).

Temperature, salinity, dissolved oxygen concentration were monitored daily in all brood tanks and the $\mathrm{pH}$ were measured twice weekly according to the standard method described in A.P.H.A. (1998). In brood tanks, mean temperature ranged from 20.0 to $30.6^{\circ} \mathrm{C}$. Mean dissolved oxygen concentrations ranged from 8.0 to $10.0 \mathrm{mgl}^{-1}$ and mean $\mathrm{pH}$ ranged from 7.4 to 8.3 . The data obtained in this study were analyzed by one-way ANOVA procedure of SAS (1988). Mean were compared by Duncan's new multiple range test (Zar, 1996).

\section{RESULTS}

\section{Reproductive Performance:}

The results obtained in Table (2) showed significant differences $(P<0.05)$ between treatments in all reproductive performance parameters. The results of total number of fry production, mean number of fry/spawning, number of fry/female, number of fry/female/day, number of fry/kg of female, number of fry/cubic meter of water and number of fry/cubic meter of water/day showed that 2 ppt treatment was the best treatment in all these reproductive performance parameters followed by 8 , 14,20 and 26 ppt treatments respectively (Table 2 and Figure1). 
Table 2. Means $( \pm$ SD) of reproductive performance during the total period of the experiment for red tilapia hybrid (Oreochromis sp.) at different levels of water salinity (110 days)

\begin{tabular}{|c|c|c|c|c|c|}
\hline 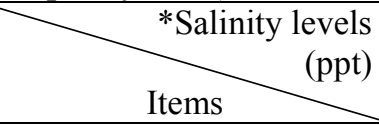 & 2 & 8 & 14 & 20 & 26 \\
\hline \multirow{2}{*}{ Total fry production } & $3554.00^{\mathrm{a}}$ & $2879.50^{\mathrm{a}} \pm$ & $1994.50^{b}$ & $1586.50^{c}$ & $773.50^{\mathrm{d}}$ \\
\hline & \pm 14.71 & 14.91 & \pm 30.85 & \pm 19.62 & \pm 9.71 \\
\hline \multirow{2}{*}{$\begin{array}{l}\text { Mean number of fry / } \\
\text { spawning }\end{array}$} & $888.50^{\mathrm{a}}$ & $719.88^{\mathrm{a}}$ & $498.62^{\mathrm{ab}}$ & $396.63^{\mathrm{ab}}$ & $193.38^{b}$ \\
\hline & \pm 8.34 & \pm 8.87 & \pm 16.17 & \pm 9.92 & \pm 6.94 \\
\hline \multirow{2}{*}{ Number of fry/ female } & $1184.67^{\mathrm{a}}$ & $959.83^{\mathrm{a}}$ & $664.83^{\mathrm{ab}}$ & $528.83^{\mathrm{ab}}$ & $257.83^{\mathrm{b}}$ \\
\hline & \pm 13.90 & \pm 4.30 & \pm 17.95 & \pm 9.87 & \pm 3.23 \\
\hline \multirow{2}{*}{$\begin{array}{l}\text { Number of fry/ female/ } \\
\text { day }\end{array}$} & $10.80^{\mathrm{a}}$ & $8.73^{\mathrm{a}}$ & $6.04^{\mathrm{ab}}$ & $4.81^{\mathrm{ab}}$ & $2.34^{\mathrm{b}}$ \\
\hline & \pm 0.12 & \pm 2.37 & \pm 1.51 & \pm 1.81 & \pm 0.93 \\
\hline \multirow{2}{*}{ Number of fry/ kg female } & $29840.47^{\mathrm{a}}$ & $24177.16^{\mathrm{a}} \pm$ & $16746.43^{\mathrm{ab}}$ & $13320.74^{\mathrm{ab}}$ & $6494.54^{b}$ \\
\hline & \pm 8.66 & 13.17 & \pm 19.73 & \pm 18.87 & \pm 6.42 \\
\hline \multirow{2}{*}{ Number of fry/ $\mathrm{m}^{3}$} & $2468.05^{\mathrm{a}}$ & $1999.65^{\mathrm{a}}$ & $1385.07^{\mathrm{ab}}$ & $1101.74^{\mathrm{ab}}$ & $537.15^{\mathrm{b}}$ \\
\hline & \pm 6.65 & \pm 4.23 & \pm 12.32 & \pm 13.80 & \pm 7.69 \\
\hline \multirow{2}{*}{ Number of fry/ $\mathrm{m}^{3} /$ day } & $22.44^{\mathrm{a}}$ & $18.18^{\mathrm{a}}$ & $12.59^{\mathrm{ab}}$ & $10.02^{\mathrm{ab}}$ & $4.88^{\mathrm{b}}$ \\
\hline & \pm 1.70 & \pm 1.03 & \pm 1.74 & \pm 1.26 & \pm 0.65 \\
\hline \multirow{2}{*}{$\begin{array}{c}\text { Mean number of spawned } \\
\text { fish }\end{array}$} & $2.13^{\mathrm{a}}$ & $1.5^{\mathrm{ab}}$ & $1.5^{\mathrm{ab}}$ & $1.38^{\mathrm{ab}}$ & $0.88^{\mathrm{b}}$ \\
\hline & \pm 0.63 & \pm 0.41 & \pm 0.41 & \pm 0.48 & \pm 0.29 \\
\hline \multirow[t]{2}{*}{ Spawned female \% } & $83.35^{\mathrm{a}}$ & $50.00^{\mathrm{b}}$ & $50.00^{\mathrm{b}}$ & $50.00^{\mathrm{b}}$ & $33.33^{\mathrm{c}}$ \\
\hline & \pm 3.57 & \pm 3.75 & \pm 3.75 & \pm 3.75 & \pm 0.01 \\
\hline \multirow[t]{2}{*}{ Total fry weight (g) } & $70.50^{\mathrm{a}}$ & $57.05^{\mathrm{ab}}$ & $42.25^{\mathrm{ab}}$ & $34.91^{\mathrm{b}}$ & $18.55^{\mathrm{c}}$ \\
\hline & \pm 3.22 & \pm 2.10 & \pm 4.00 & \pm 4.73 & \pm 1.34 \\
\hline \multirow{2}{*}{$\begin{array}{c}\text { Mean of fry weight } \\
\text { (g)/spawning }\end{array}$} & $17.63^{\mathrm{a}}$ & $14.26^{\mathrm{a}}$ & $10.56^{\mathrm{a}}$ & $8.73^{\mathrm{ab}}$ & $4.64^{\mathrm{b}}$ \\
\hline & \pm 3.08 & \pm 3.27 & \pm 3.50 & \pm 3.65 & \pm 0.33 \\
\hline \multirow[t]{2}{*}{ Mean of rest period (day) } & $16.87^{\mathrm{b}}$ & $18.12^{\mathrm{b}}$ & $25.00^{\mathrm{a}}$ & $25.75^{\mathrm{a}}$ & $21.25^{\mathrm{ab}}$ \\
\hline & \pm 0.70 & \pm 0.01 & \pm 2.12 & \pm 2.82 & \pm 2.12 \\
\hline \multirow[t]{2}{*}{ Egg diameter $(\mu \mathrm{m})$} & $25.35^{\mathrm{a}}$ & $25.50^{\mathrm{a}}$ & $23.72^{\mathrm{b}}$ & $22.15^{\mathrm{c}}$ & $22.26^{\mathrm{c}}$ \\
\hline & \pm 1.39 & \pm 0.76 & \pm 1.23 & \pm 1.41 & \pm 0.70 \\
\hline
\end{tabular}

*Values in rows having the same superscript letters are not significantly different $(P \geq 0.05)$

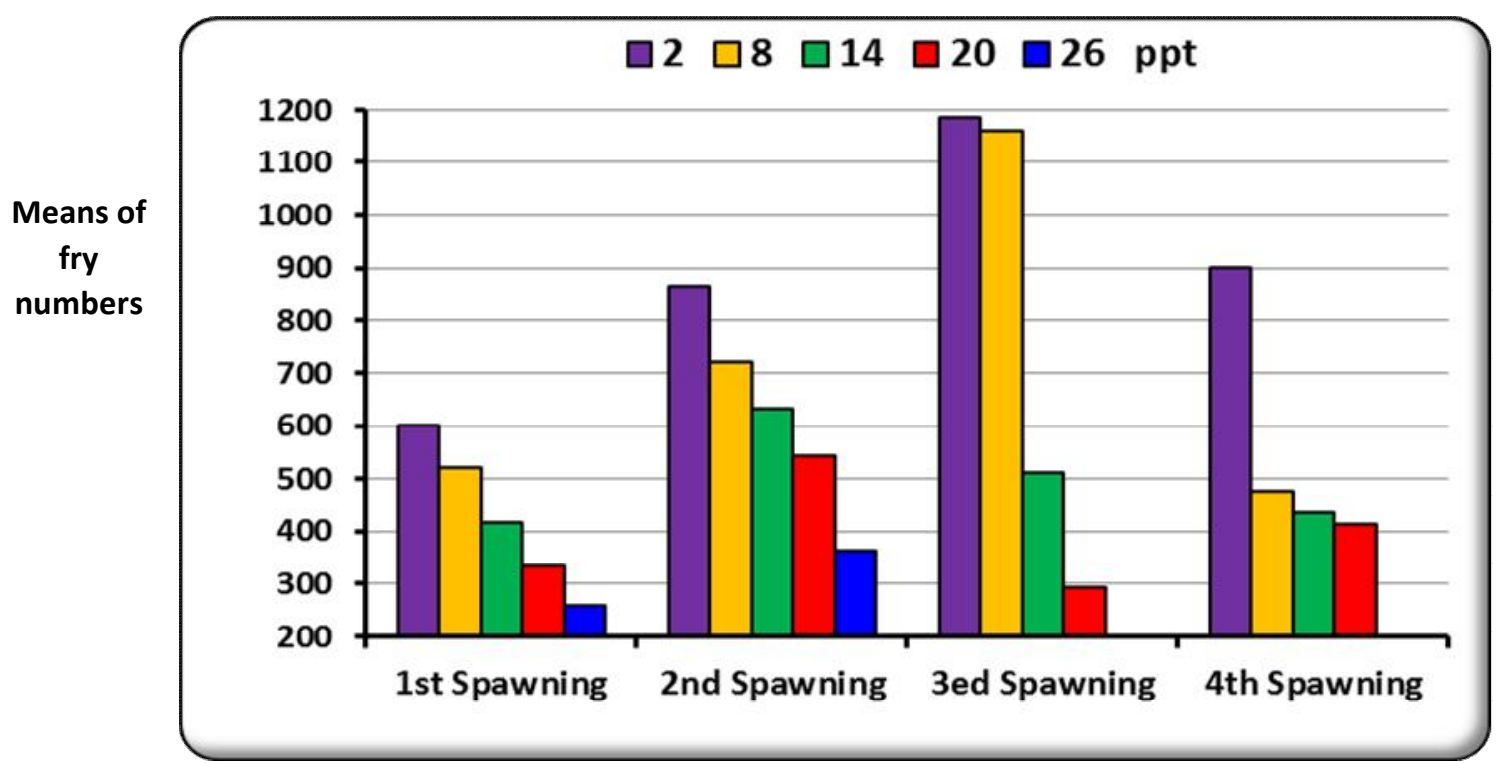

Fig. 1. Means of fry numbers of red tilapia during the four spawnings at different levels of water salinity

There were significant differences $(P<0.05)$ between treatments in red tilapia hybrid (Oreochromis $s p$ ) incubated eggs diameter at micrometer taken from fish mouth after 110 days exposure to different levels of water salinity; $2,8,14$, 20 and 26 ppt. The smallest egg diameter $(22.15 \pm$ 
1.41) was recorded for $20 \mathrm{ppt}$ treatment and the largest one $(25.50 \pm 0.76)$ was recorded for $8 \mathrm{ppt}$ treatment (Table 2).

Significant differences between treatments $(P<0.05)$ also were recorded for spawned female $(\%)$ parameter with the minimum value was recorded for $26 \mathrm{ppt}$ and the maximum value for $2 \mathrm{ppt}$ treatment (Table 2). Also the lowest weight of the mean of fry weight $(\mathrm{g}) /$ spawning was recorded for $26 \mathrm{ppt}$ and the highest one for $2 \mathrm{ppt}$ treatment. The shorter rest period of all spawnings was recorded for 2 and $8 \mathrm{ppt}$ treatments and the longer rest period for $20 \mathrm{ppt}$ treatment (Table 2).

\section{Histological Examination The Ovaries}

The normal structure of red tilapia ovary including ovarian follicles, primary and secondary oocytes are shown in Figure 2. Figure 3 shows cross sections of red tilapia ovaries after 110 days exposure to 2 ppt water salinity. The stop of growth and maturation in oocytes in first stage, malformation of some oocyte, complete lysis of yolk materials, degenerated oocytes and atretic phase were observed (Figure 3).

The results show an atresia, the first stage (oil droplets), inter follicular edema, fibrosis, inflammation, degeneration nuclei, rupture ripe follicle in inter follicular spaces and desquamated of oocytes liningin ovaries of red tilapia after 110 days exposure to 8 ppt water salinity (Figure 4). Abnormal malformed oocytes, abnormal ripe oocytes with lysis of yolk materials, completed degeneration of oocyte and abnormal oocytes with atresia were observed in the ovaries of red tilapia after 110 days exposure to 14 ppt water salinity (Figure 5).

Figure 6 shows cross sections of red tilapia ovaries after 110 days exposure to $20 \mathrm{ppt}$ water salinity. A separation of epithelial lining of oocytes, severe damage of oocytes, follicle represented by irregular shape of oocyte follicle, complete lysis of yolk materials and some oocyte have atretic phase were observed (Figure 6). An abnormal ripe oocytes, rupture ripe follicle in inter follicular spaces with degenerated oocytes, rupture of oocytes, complete degeneration of oocytes, severe damage and moderate lysis of yolk materials and atresia with irregular shape of oocytes were recorded for red tilapia ovaries after 110 days exposure to $26 \mathrm{ppt}$ water salinity (Figure 7).

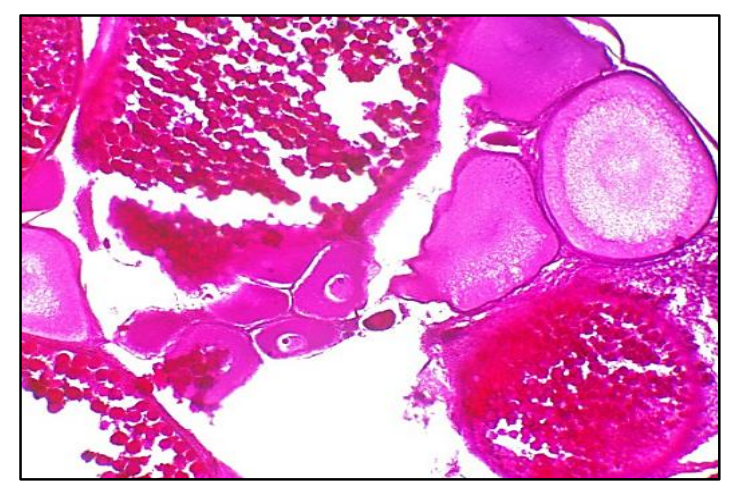

Fig. 2. Photomicrograph of untreated red tilapia hybrid ovaries stained by $\mathrm{Hx}$ and $\mathrm{E}$ stain $100 \mathrm{X}$

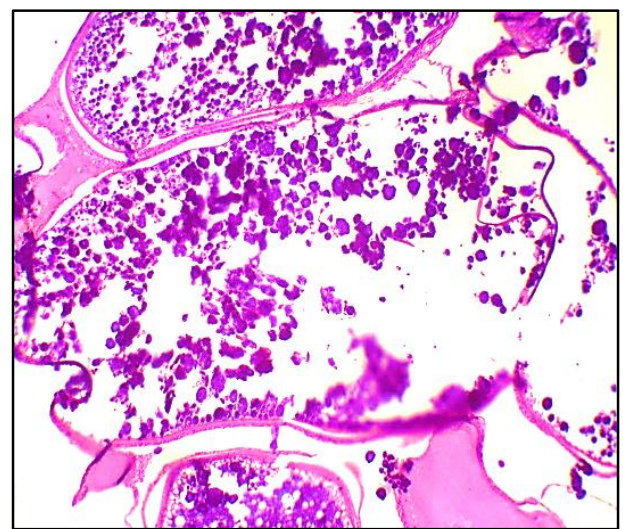

Fig.3. Photomicrograph of red tilapia hybrid ovaries (after 110 days exposure to water salinity 2 ppt) stained by $\mathrm{Hx}$ and $\mathrm{E}$ stain $100 \mathrm{X}$

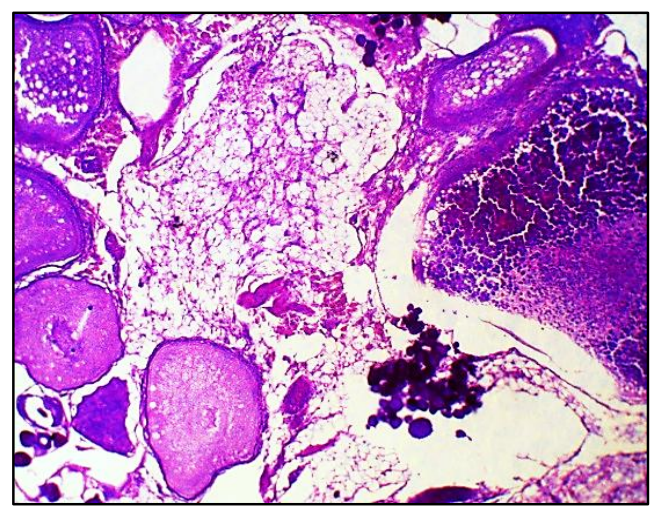

Fig.4. Photomicrograph of red tilapia hybrid ovaries (after 110 days exposure to water salinity 8 ppt) stained by $H x$ and $E$ stain $100 X$ 


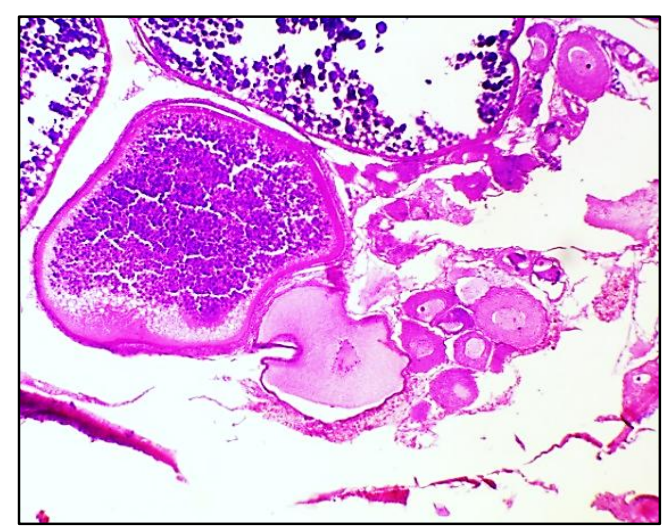

Fig.5. Photomicrograph of red tilapia hybrid ovaries (after 110 days exposure to water salinity 14 ppt) stained by $\mathrm{Hx}$ and $\mathrm{E}$ stain $100 \mathrm{X}$

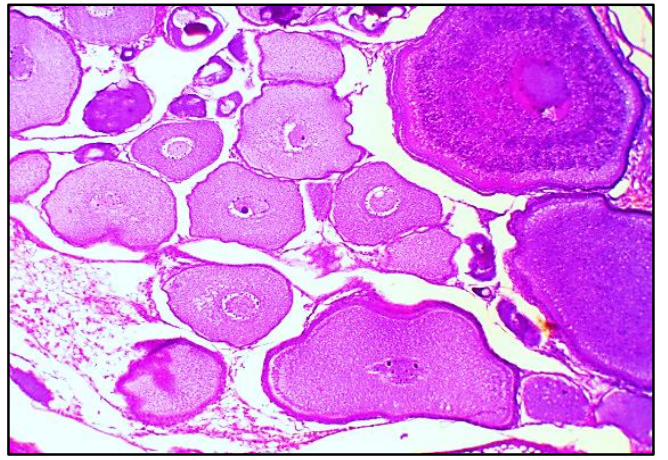

Fig.6. Photomicrograph of red tilapia hybrid ovaries (after 110 days exposure to water salinity 20 ppt) stained by $\mathrm{Hx}$ and $\mathrm{E}$ stain $100 \mathrm{X}$

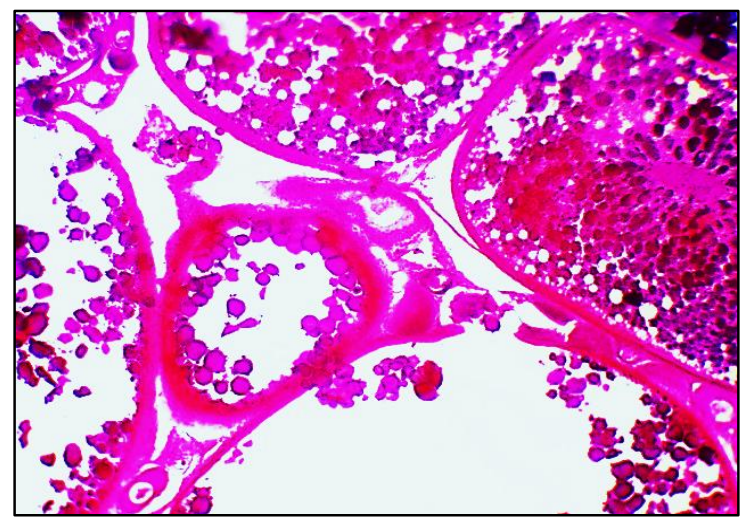

Fig.7. Photomicrograph of red tilapia hybrid ovaries (after 110 days exposure to water salinity 26 ppt) stained by $\mathrm{Hx}$ and $\mathrm{E}$ stain $100 \mathrm{X}$

The Testes:

The normal structure of red tilapia hybrid testes including spermatogonia, primary, secondary spermatocytes and spermatozoa are shown in Figure 8. Figure 9 shows cross sections of red tilapia hybrid testes after 110 days exposure to 2 ppt water salinity. Complete damage of seminiferous follicle, multinectotic cells, severe damage of seminiferous follicles, aggregation of multinucleated cells, degenerated of sperm tails and complete empty or severe edema in seminiferous follicles are observed (Figure 9).
The results show severe damage in sperm cells and in seminiferous follicles with necrotic appearance, multinecrosis in seminiferous follicles, loss of testicular capsule in many seminiferous tubules, empty of seminiferous follicles, aggregation of multinucleated cells and degenerated of sperm cells were recorded in cross sections of red tilapia hybrid testes after 110 days exposure to 8 ppt water salinity (Figure 10). Reduction of sperm follicle, aggregation of multinucleated cells, degeneration of sperm tail, deformation of seminiferous follicles, deeply dark testicular capsules, desquamated of follicular sheath and aggregation of sperm cells in 
some seminiferous tubules were observed in cross sections of red tilapia hybrid testes after 110 days exposure to $14 \mathrm{ppt}$ water salinity (Figure 11).

Figure 12 shows cross sections of red tilapia hybrid testes after 110 days exposure to $20 \mathrm{ppt}$ water salinity. Severe damage of seminiferous follicles, completely empty with multinecrotic area of seminiferous follicles, inflammation of seminiferous follicles with appearance of hemosiderin granules and complete atrophy of seminiferous follicles were recorded (Figure 12). A complete atrophy, severe deformed of seminiferous follicles with necrotic appearance, aggregation of multinucleated cells, degenerated of sperm cells, lose of seminiferous follicles structure, necrotic appearance, multinecrotic areas in seminiferous follicles, aggregation of multinucleated cells and deeply dark of testicular capsules were observed in cross sections of red tilapia hybrid testes after 110 days exposure to $26 \mathrm{ppt}$ water salinity (Figure 13).

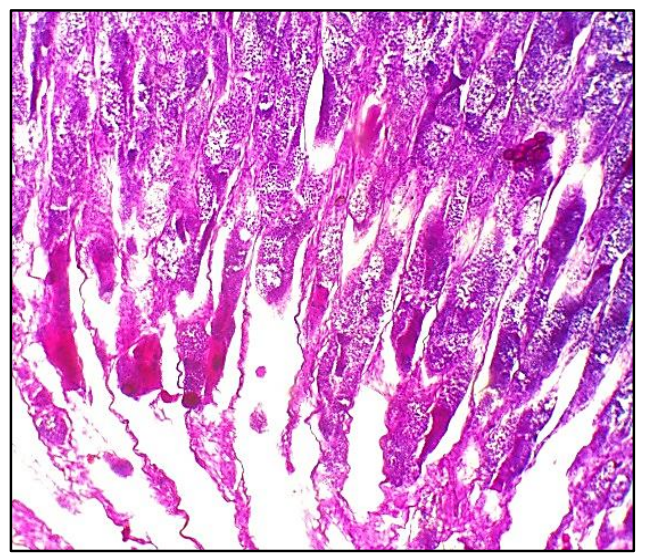

Fig.8. Photomicrograph of untreated red tilapia hybrid testes stained by $\mathrm{Hx}$ and $\mathrm{E}$ stain $100 \mathrm{X}$

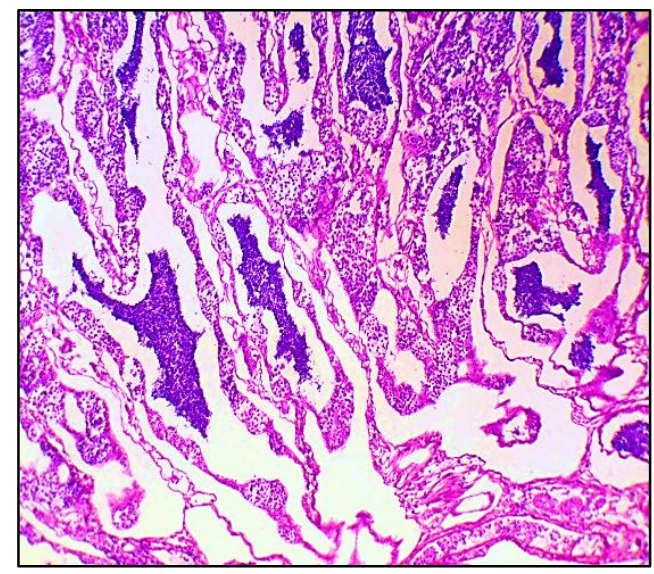

Fig.9. Photomicrograph of red tilapia hybrid testes (after 110 days exposure to water salinity 2 ppt) stained by $H x$ and E stain $100 X$

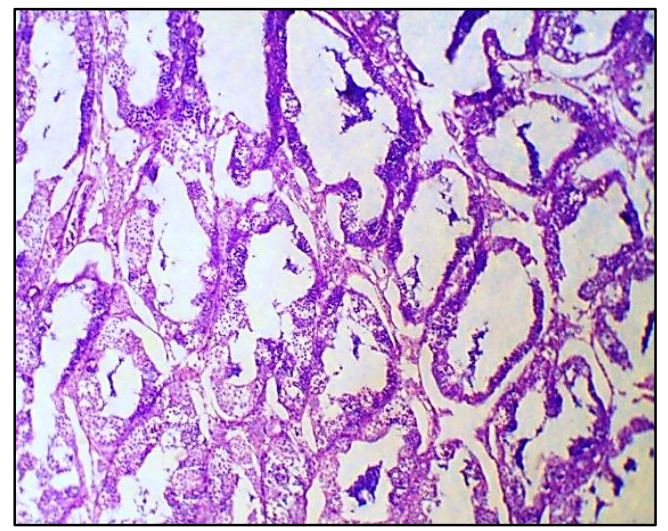

Fig.10. Photomicrograph of red tilapia hybrid testes (after 110 days exposure to water salinity 8 ppt) stained by $\mathrm{Hx}$ and $\mathrm{E}$ stain $100 \mathrm{X}$ 


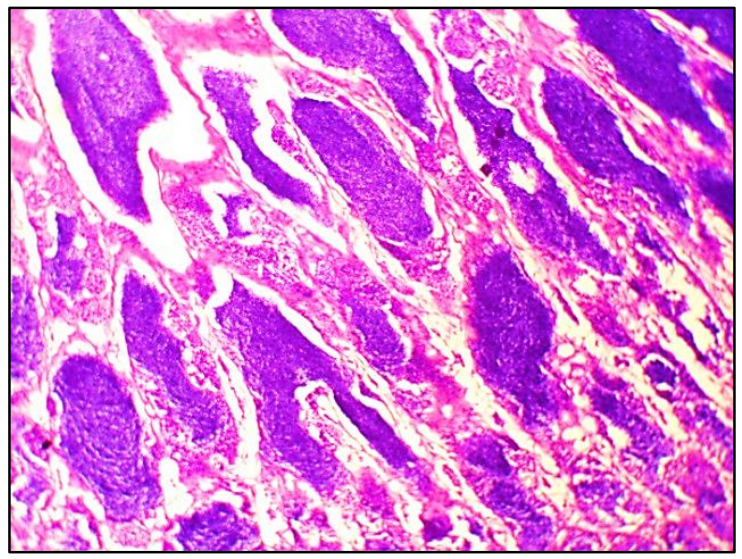

Fig.11. Photomicrograph of red tilapia hybrid testes (after 110 days exposure to water salinity 14 ppt) stained by $\mathrm{Hx}$ and $\mathrm{E}$ stain $100 \mathrm{X}$

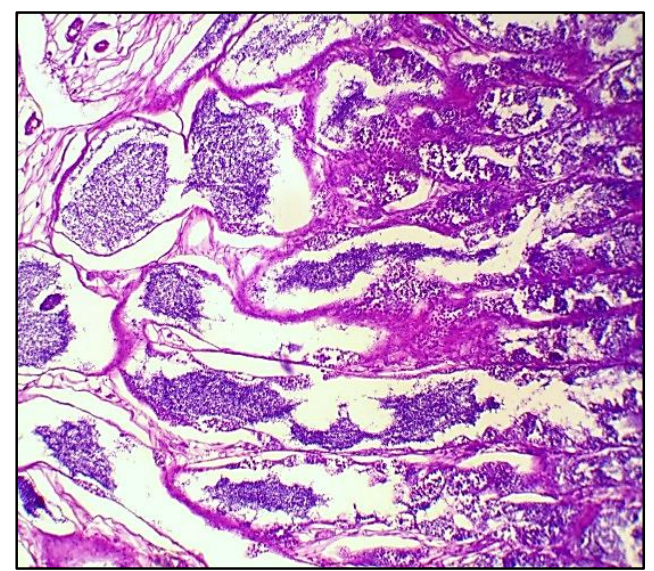

Fig.12. Photomicrograph of red tilapia hybrid testes (after 110 days exposure to water salinity 20 ppt) stained by $H x$ and E stain $100 X$

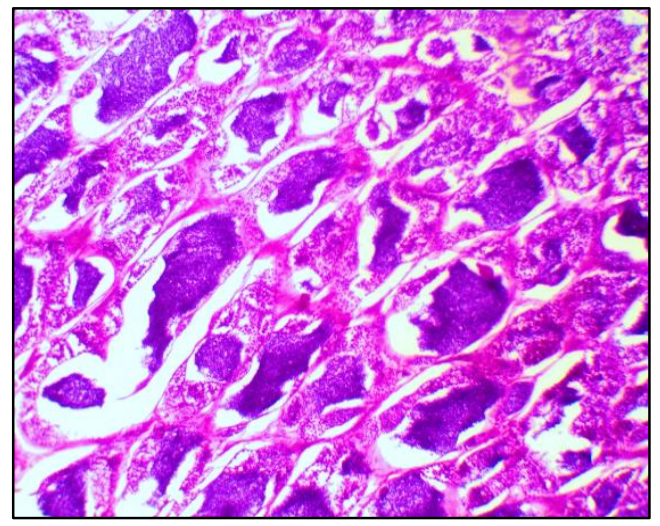

Fig.13. Photomicrograph of red tilapia hybrid testes (after 110 days exposure to water salinity 26 ppt) stained by $H x$ and E stain $100 X$ 


\section{DISCUSSION}

The present results suggest that red tilapia hybrid broodstock may be maintained under different salinities without impairing fry production, further suggesting that a hatchery facility using brackish water would be practical in Egypt where fresh water resources are limited. The advantages of improved reproductive capacity at high salinities, however, must be weighed against the increased possibility of introduction into marine environments. These are in agreement with (Watanabe et al., 1989b). Uchida and King (1962) reported that $O$. mossambicus fry production was approximately three times higher in brackish water (8.9-15.2 ppt) than in freshwater and suggested that a commercial rearing facility use brackish water to reduce the high cost of freshwater.

In the present study, an inhibitory effect of high salinity on reproduction was evidenced by considerably fewer spawnings in 20 and 26 ppt than in 2, 8 and 14 ppt. These results should be interpreted with caution, however, as resorption of ripe spawns is a common phenomenon in tilapias and the number of completed spawnings may not necessarily indicate the number of spawns actually elaborated by a given fish (Peters, 1983). An apparently anomalous result was that total spawnings were lowest among females in 26 ppt. In tilapias, early maturity at small sizes is thought to be a common response to unstable or stressful environmental conditions (Payne, 1983). Therefore, greater spawning activity in high brackish water 2 to $14 \mathrm{ppt}$ may have been related to the salinity exposure history of these individuals. Alternatively, infrequent spawning in freshwater may have resulted from greater resorption of ripe spawns for reasons which are presently unclear.

Lee (1979) further observed that when fry were removed from mouthbrooding females from 14 to 18 days following spawning, spawning occurred again after 7 to 12 days. In the present study, results are closely similar to those determined by him. He concluded that parental care (mouthbrooding) suppresses expression of the full reproductive potential in tilapias and that egg or fry removal has the effect of shortening the time interval between spawnings. Present observations on spawning intervals during natural release of fry appear to support this idea. It is evident, however, that spawning intervals vary widely, even under conditions of early egg removal. Resorption of ripe spawns may have contributed to these results. The proposed effect of egg or fry removal on the spawning interval implies a direct relationship between time of removal and the time interval between successive spawnings. However, the inhibitory effect of high salinity on reproduction was evidenced by considerably lowered hatching successes at 20 and 26 ppt.

Production rate of Florida red tilapia seed in fresh and brackish water tanks of broodstock management is among the highest values reported for intensive tank culture of tilapias (Watanabe et al., 1988). Previous reports ranged from 6-7 seed $\mathrm{m}^{-2}$ day $^{-1}$ for O.aureus x O.niloticus hybrids (Balarin and Haller, 1982) to 55 seed $\mathrm{m}^{-2}$ day $^{-1}$ for O. mossambicus (Uchida and King, 1962). Ernst et al. (1991) determined that seed production of Florida red tilapia was higher at $5 \mathrm{ppt}\left(78 \mathrm{seed}^{-2}\right.$ day $\left.^{-1}\right)$ than at $18 \mathrm{ppt}$ (47 seed $\mathrm{m}^{-2}$ day $^{-1}$ ). Relatively high seed production in the present study (22.44 seed $\mathrm{m}^{-3}$ day $^{-1}$ ) suggests that reproductive performance of red tilapia may be maximized under salinity $(2 \mathrm{ppt})$.These results are in disagreement with the findings that were reported by Febry and Lutz (1987) who found that relatively high seed production in Florida red tilapia may be maximized (91.7 seed $\mathrm{m}^{-2}$ day $^{-1}$ ) under an isoosmotic salinity (12 ppt).

In the current study, the different stages of eggs in the red tilapia ovaries are indicative of the long spawning period. The larger eggs are, the stocks most likely to be shed first, while the maturing stocks will mature subsequently. The best method for determining, if multiple spawning is occurring, is a histological examination. This must be done if the fish species is a multiple spawner. The frequency of multiple spawning can be determined by using postovulatory follicles. Ovaries can also be distinguished between immature and postovulatory ovaries by using histology, that is, atresia can easily be seen. Keeping the red tilapia at salinity levels from 14 to $26 \mathrm{ppt}$ for long periods of time would result in the arrest of egg development and atresia of all vitellogenic oocytes, thus reducing oogenesis within individual fish as well as within a population to a uniform state, after which subsequent exposure to a normal high salinity would trigger rapid and synchronous oocyte maturation and ovulation (Srisakultiew and Wee, 1988).

\section{CONCLUSION}

In general, spawning of Florida red tilapia in freshwater is better than in brackish water. Whereas fry production is inhibited under salinities (14-26 ppt).

\section{REFERENCES}

A.P.H.A., 1998. Standard Methods for the Examination of Water and Wastewater, $20^{\text {th }}$ edition. American Public Health Association, Washington, D.C.

Balarin J.D. and R. D. Haller, 1982. The intensive culture of tilapia in tanks, raceway and cages. In: Muir, J.F., Roberts, R.J. (Eds.), recent advances in aquaculture. Westview, Boulder, 266-355.

Chang P.H. and J. A. Plumb, 1996. Effects of salinity in Streptococcus infection of Nile tilapia, Oreochromis niloticus. J. Appl. Aquacult., 6: 3945. 
Coward K. and N. R. Bromage, 2000. Reproductive physiology of female tilapia broodstock. Reviews in Fish Biology and Fisheries, 10: 1-25.

de Azevedo R.V.,K. dos Santos-Costa, K.F. de Oliveira, F. Flores-Lopes, E.A. Teixeira-Lanna, and L.G. Tavares-Braga, 2015. Responses of Nile tilapia to different levels of water salinity. Lat. Am. J. Aquat. Res., 43(5): 828-835.

Ernst D.H., W. O. Watanabe, L.J. Ellingson, R.I. Wicklund, and E.L. Olla, 1991. Commercial scale production of Florida red tilapia seed in low- and brackish-salinity tanks. J. World Aquacult. Sot., 22(1): 36-44

Febry, R. and P. Lutz, 1987. Energy partitioning in fish: the activity-related cost of osmoregulation in a euryhaline cichlid. J. Exp. Biol., 128: 63-85.

Fineman-Kalio A.S., 1988. Preliminary observations on the effect of salinity on the reproduction and growth of freshwater Nile tilapia, Oreochromis niloticus (L.), cultured in brackish water ponds. Aquaculture and Fisheries Management, 19: 313320.

Hopkins K. D., M. Ridha, D. Leclercq and T. A. AlAhmad, 1985. Screening tilapias for sea water culture in Kuwait. Interim Report, 15 pp. Mariculture and Fisheries Department, Kuwait Institute for Scientific Research and International Center for living Aquatic Resources Management.

Lee J.C., 1979. Reproduction and hybridization of three cichlid fishes, Tilapia aurea (Steindachner), $T$. hornorum (Trewavas) and $T$. nilotica (Linnaeus) in aquaria and plastic pools. Ph.D. Dissertation. Auburn University, AL, 84 pp.

Liao I.C. and S. L. Chang, 1983. Studies on the feasibility of red tilapia culture in saline water. Pages 524-533 in L. Fishelson and Z. Yaron, compilers. Proceedings of the International Symposium on Tilapia in Aquaculture, Nazareth, Israel, 8-13 May 1983. Tel Aviv University. Tel Aviv.

Little D.C. and G. Hulata, 2000. Strategies for tilapia seed production. In: Beveridge, M.C.M. and McAndrew, B.J. (eds) Tilapias: Biology and Exploitation. Kluwer Academic Publishers, Dordrecht, Boston, London, 267-326.

Mommsen T., 1998. Growth and metabolism. In: Evans D. (ed) The Physiology of Fishes, $2^{\text {nd }}$ edition, CRC Press, Boca Raton, pp. 65.

Payne A. I., 1983. Estuarine and salt tolerant tilapias. In: L. Fishelson and Z. Yaron (Compilers), International Symposium on Tilapia in Aquaculture, Nazareth, Israel, Tel Aviv University, Israel, 534-543.

Pearse A.G., 1972. Histochemistry: theoretical and applied. Volume 1. Churchill Livingstone publisher, London.

Peters H. M. 1983. Fecundity, egg weight and oocyte development in tilapia (Cichlidae, Teleostei).
ICLARM Translations 2. ICLARM, Manila, Philippines, $28 \mathrm{pp}$.

SAS, 1988. Statistical Analysis Systems user's guide. Statistics A.A. Ray. Ed. SAS Institute, North Carolina, USA, $1028 \mathrm{pp}$.

Siraj S.S., R.O. Smitherman, S. Castillo-Galluser and R. A. Dunham, 1983. Reproductive traits of three classes of Tilapia nilotica and maternal effects on their progeny. In: Fishelson, L., Yaron, Z. (Eds.), Proc. $1^{\text {st }}$ Int. Symp. On Tilapia in Aquaculture. Tel Aviv Univ. Press, Israel, 210-218.

Srisakultiew P. and K. L. Wee, 1988. Synchronous spawning of Nile Tilapia through hypophysation and temperature manipulation. In: The $2^{\text {nd }}$ International Symposium on Tilapia in Aquaculture (ed Pullin RSV, Bhukaswan, T., Toguthai, K. and Maclean, J.L.). Department of Fisheries, Bangkok, Thailand and ICLARM, Manila, Philippines, ICLARM conference proceedings Bangkok, Thailand, pp 275-284.

Uchida R.N. and J. E. King, 1962. Tank culture of tilapia. U.S. Fishery Bulletin 199(62):2147.

Watanabe W.O. and C. M. Kuo, 1985. Observations on the reproductive performance of Nile tilapia (Oreochromis niloticus) in laboratory aquaria at various salinities. Aquaculture, 49: 315-323.

Watanabe W.O.,K. M. Burnet, B. L. Olla and R. I. Wicklund, 1989b.The effects of salinity on reproductive performance of Florida red tilapia. Journal of the World Aquaculture Society, 20: 223-229.

Watanabe W.O.,L. J. Ellingson, R. I. Wicklund and B. L. Olla, 1988. The effects of salinity on growth, food consumption and conversion in juvenile, monosex male Florida red tilapia. P 515-523 In: R.S. Pullin, T. Bhukasavan, K. Tonguthai and J.L. Maclean, editors. The $2^{\text {nd }}$ International Symposium on Tilapia in Aquaculture. ICLARM Conference Proceedings 15, 623 p. Department of Fisheries, Bangkok, Thailand and International Center for Living Aquatic Resources Management, Manila, Philippines.

Watanabe, W.O., K. E. French, D. H. Ernst, B. L. Olla and R. I. Wicklund 1989a. Salinity during early development influences growth and survival of Florida red tilapia in brackish and seawater. Journal of the World Aquaculture Society, 20: 134-142.

Watanabe W.O., S. J. Smith, R. I. Wicklund and B. L. Olla, 1992. Hatchery production of Florida red tilapia seed in brackish water tanks under naturalmouthbrooding and clutch-removal methods. Aquacullure, 102: 77-88.

Wohlfarth G.W. and G. I. Hulata, 1983. Applied genetics of tilapias. ICLARM Studies and Reviews $6,2^{\text {nd }}$ edition. International Center for Living Aquatic Resource Management, Manila, Philippines, $26 \mathrm{pp}$. 
Zar J.H. 1996. Biostatistical analysis. Prentice Hall, Upper Saddle River, Nj, USA.

الأداء التناسلي والفحص النسيجي لمناسل أمهات البلطي الأحمر الهجين المُربى في مستويات مختلفة من ملوحة المياه جابر دسوقى إبراهيم حسنين'، محمد عبد الباقى عامر '، محمد سالم أحمد'، هبة السيد عبد التبي' ا ـ قسم الثروة السمكية والأحياء المائية، كلية العلوم الزراعية البيئية، جامعة العريش، ب - قسم الإنتاج الحيواني، كلية الزراعة، جامعة عين شعس

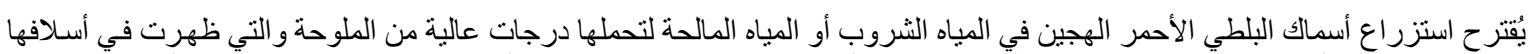

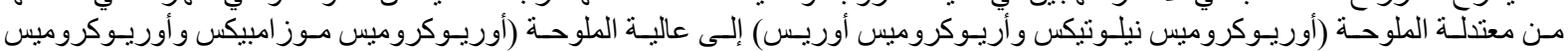

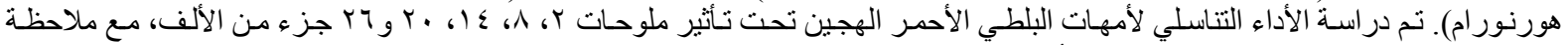

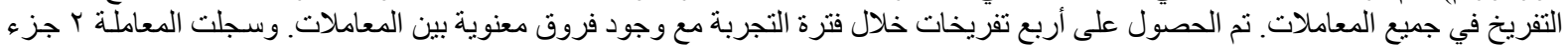

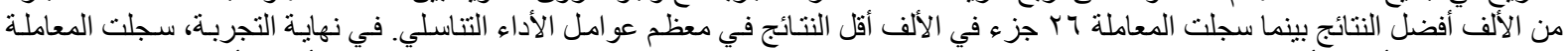

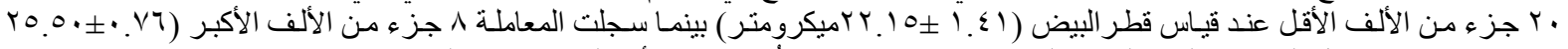
ميكرومتر ). وتم تسجيل التغير عات الهستولوجية التي ظهرت في مبايض وخُصى هذه الأسماك بعد انتهاء التجربة. 